\title{
Analisis Penerapan Perencanaan Pajak (Tax Planning) dalam Upaya Penghematan Beban Pajak Penghasilan Badan pada PT DCM Tahun 2017
}

\author{
Abdul Rahmat ${ }^{1 *}$ Johansyah Zaini $^{2}$ \\ 12 Institut Ilmu Sosial dan Manajemen STIAMI, Jakarta, Indonesia \\ 1 abdul_rahmat@gmail.com \\ * corresponding author
}

\section{ARTICLE INFO}

\section{Keywords}

Tax Planning,

Implementation, Zakat as a

reduction of taxable

income, LAZISMU

\begin{abstract}
This study aimed to analyze the implementation of the zakat policy as a reduction of taxable income of individual taxpayers at the LAZISMU office in Central Jakarta in 2018, and also to analyze the inhibiting entities faced, as well as the driving entities for LAZSIMU office in implementing the zakat policy as a reduction of taxable income of individual taxpayers. This research used a descriptive qualitative approach. The results showed that the implementation of the zakat policy as a reduction of taxable income of individual taxpayers at the LAZISMU office in Central Jakarta in 2018 according to the six factors used by the writer, policy size and objectives, resources, communication between organizations, character of implementing agents, disposition (tendencies/attitudes) of implementers, social, economic and political environments have been fulfilled. However, there are still some obstacles faced by LAZISMU in implementing the zakat policy as a reduction of taxable income, such as size and policy objectives, social and political environmental conditions, and support and participation of taxpayers in supporting this policy. Therefore the government must evaluate and overcome the obstacles in the implementation of the zakat policy as a reduction of taxable income.
\end{abstract}

\section{PENDAHULUAN}

Indonesia merupakan negara yang memiliki jumlah penduduk yang cukup besar. Indonesia menempati urutan keempat dunia dengan jumlah penduduk mencapai 268,369,114 (berdasarkan worldometers) pada tahun 2019. Hal ini tentu menjadi potensi yang sangat besar bagi perekonomian bangsa apabila SDM di Indonesia memiliki kualitas yang baik.

Selain memiliki jumlah penduduk yang banyak, Indonesia juga memiliki keberagaman mulai dari Suku, Budaya, dan Agama. Suku sendiri di Indonesia terdapat banyak macamnya di setiap daerah. Daerah yang tersebar di Indonesia selain memiliki suku juga memiliki budaya yang beragam. Kebudayaan itupun dibagi lagi kedalam banyak aspek, mulai dari aspek sosial dan adat istiadat..

\section{Ruang Lingkup Penelitian}

Karena luasnya ruang lingkup permasalahan dan materi terkait dengan masalah yang diteliti maka peneliti membatasi permasalahan sebagai berikut :

1. Zakat yang dimaksud dalam penelitian ini hanya Zakat mal (profesi)

2. Penghasilan kena pajak hanya dibatasi pada penghasilan orang pribadi

3. Entitas penghambat dan pendorong dalam pelaksanaan kebijakan zakat sebagai pengurangan penghasilan kena pajak wajib pajak orang pribadi.

\section{Tujuan Penelitian} adalah :

Berdasarkan pertanyaan penelitian yang telah dirumuskan oleh peneliti maka tujuan dari penelitian ini

1. Untuk Menganalisis Bagaimana Implementasi Zakat Sebagai Pengurang Penghasilan Kena Pajak Wajib Pajak Orang Pribadi Pada Kantor LAZISMU di Jakarta Pusat Tahun 2018

2. Untuk Menganalisis Entitas Penghambat yang Dihadapi Dalam Implementasi Zakat Sebagai Pengurang Penghasilan Kena Pajak Wajib Pajak Orang Pribadi pada Kantor LAZISMU di Jakarta Pusat tahun 2018 
3. Untuk Menganalisis Entitas Pendorong yang dilakukan dalam Implementasi Zakat Sebagai Pengurang Penghasilan Kena Pajak Wajib Pajak Orang Pribadi Pada Kantor LAZISMU di Jakarta Pusat Tahun 2018.

\section{KAJIAN LITERATUR}

\section{Administrasi}

Administrasi secara umum adalah suatu bentuk usaha atau kegiatan yang berkaitan dengan pengaturan kebijaksanaan untuk mencapai tujuan.Administrasi secara sempit ialah suatu kegiatan yang meliputo catat mencatat, surat-menyurat, pembukuan sederhna dan sebagainya yang memiliki sifat teknis ketatausahaan (sumber : Wikipedia)

Menurut Siagian (2008;2) administrasi adalah satu keseluruhan proses kerjasama antara dua orang manusia atau lebih yang didasarkan atas rasionalitas tertentu untuk mencapai tujuan yang telah ditentukan sebelumnya.

\section{Kebijakan Publik}

Menurut James Anderson (1975, dalam Tangkilisan (2003:2) mengartikan: “Kebijakan publik sebagai kebijakan-kebijakan yang dibuat oleh lembaga atau pejabat pemerintah." Lebih jauh Andereson mencatat ada 5 (lima) implikasi dan konsepnya mengenai kebijakan publik tersebut yaitu:

1. Kebijakan publik adalah tindakan yang berorientasi pada tujuan

2. Kebijakan publik berisikan rangkaian tindakan yang diambil sepanjang waktu

3. Kebijakan publik merupakan tindakan dari kebutuhan akan adanya suatu kebijakan mengenai halhal tertentu

\section{Perpajakan}

Definisi pajak menurut Adriani yang dikutip oleh Diana (2013: 34):

"Pajak adalah iuran kepada kas negara (yang dapat dipaksakan) yang terutang oleh yang wajib membayarkan menurut peraturan-peraturan, dengan tidak mendapat prestasi kembali yang langsung dapat ditujukan dan yang gunanya adalah untuk membiayai pengeluaran-pengeluaran umum berhubungan dengan tugas negara untuk menyelanggarakan pemerintahan."

Sedangkan menurut Djajadiningrat yang dikutip oleh Diana (2013: 34):

"Pajak adalah suatu kewajiban untuk menyerahkan sebagian kekayaan negara karena suatu keadaan, kejadian,dan perbuatan yang memberikan kedudukan tertentu. Kedudukan tersebut bukan sebagai hukuman, tetapi menurut peraturan-peraturan yang ditetapkan pemerintah serta dapat dipaksakan. Untuk itu, tidak ada jasa balik dari negara secara langsung, misalnya untuk memelihara kesejahteraan umum."

\section{Zakat}

Zakat ditinjau dari segi bahasa (lughatan) mempunyai

beberapa arti, yaitu keberkahan (al-barakatu), pertumbuhan, dan perkembangan (al-nama') kesucian al taharatu) dan keberesan (al-salahu).Sedangkan arti zakat secara istilah (shar'iyah) ialah bahwa zakat itu merupakan bagian dari harta dengan persayaratan tertentu, yang ALLAH SWT mewajibkan kepada pemiliknya untuk diserahkan kepada yang berhak menerimanya,dengan persayaratan tertentu pula.(ismail nawawi:2013)

Sedangkan pengertian zakat menurut Sabiq (2008: 7),yang dimaksud dengan zakat adalah :

"Zakat adalah suatu sebutan dari suatu hak ALLAH yang dikeluarkan oleh seseorang untuk fakir miskin,Dianamakan zakat karena dengan dikeluarkan nya zakat didalamnya terkandung harapan untuk memperoleh berkah , pembersihan jiwa dan sifat kikir bagi orang kaya atau menghilangkan rasa iri hati orangorang miskin dan memupuknya dengan berbagai kebijakan."

\section{Kerangka Konseptual}

Seperti pendapat yang dikemukakan oleh Van Meter dan Van Horn (Subarsono, 2006 :99) mengatakan Bahwa Implementasi kebijakan meliputi kebijakan-kebijakan yang meliputi kebijakan-kebijakan oleh individu umum atau pribadi.Implementasi yang digunakan dalam penelitian ini menggunakan implementasi yang di utarakan oleh Van Meter dan Van Horn.Secara teoritis terdapat 6 faktor yaitu standar dan sasaran, sumber daya, hubungan antara oraganisasi, karakteristik agen pelaksana, disposiosi implementor, dan kondisi sosial politik dan ekonomi. 
Dalam Hal ini berarti setiap faktor saling berhubungan dan berkaitan. Apabila setiap hal tersebut berjalan dengan baik maka akan timbul keselaraasan. Pertama sumber daya dalam penelitian ini adalah seluruh bagian yang menjadi terciptanya dan terselenggaranya penerimaan zakat pada LAZISMU di Jakarta Pusat. Organisai yang berkaitan ialah Pemerintah dan Baznas sebagai pengawas menjalankan nya setiap kegiatan penerimaan Zakat. Kemudian Karakteristik Agen Pelaksana berarti setiap hal yang menjadi pelaksana nya dan Sasaran nya adalah para Muzakki (wajib zakat) yang sekaligus menjadi Wajib Pajak.

\section{METODE PENELITIAN}

\section{Pendekatan Penelitian}

Pendekatan penelitian yang penulis gunakan adalah pendekatan kulaitatif. Menurut Cresswell (2014:4): "Penelitian Kualitatif merupakan metode-metode untuk mengeksplorasi dan memahami makna yang dibuat oleh sejumlah individu atau sekelompok orang dianggap berasal dari masalah sosial atau kemanusiaan".

Sedangkan menurut Satori (2012: 22), Pendekatan dan jenis penelitian sebagai berikut, "Penelitian kualitatif adalah penelitian yang menekankan pada Quality atau hal yang terpenting dari sidat suatu barang dan Jasa berupa kejadian atau fenomena atau gejala sosial yang merupakan makna dibalik kejadian yang dapat dijadikan pelajaran berharga bagi suatu konsep teori."

\section{Jenis Penelitian}

Penggolongan jenis-jenis penelitian akan sangat bergantung dari sisi mana peneliti ingin meninjau persoalan atau permasalahan yang dibahas.Seacara umum penelitian memiliki beberapa jenis diantaranya :

\section{Penelitian berdasarkan tempat pelaksanaanya :}

1. Penelitian Lapangan

Yaitu penelitian yang secara langsung dilakukan di lokasi peneletian langsung dengan mengadakan observasi dan pengamatan dalam memperoleh data yang diperlukan.Pada penelitian ini peneliti melakukan penelitian pada Kantor LAZISMU Jakarta Pusat.

Penelitian Lapangan :

\section{Teknik Wawancara}

Wawancara merupakan alat rechecking atau pembuktian terhadap informasi atau keterangan yang diperolej sebelumnya.

Menurut Sugiyono (2013 : 231), teknik wawancara adalah, "Wawancara merupakan pertemuan dua orang untuk bertukan informasi dan ide melalui tanya jawab, sehingga dapat dikontruksikan makna dalam suatu topik tertentu."

\section{Penelitian Kepustakaan}

Penelitian ini bertujuan untuk mengumpulkan data dan memperolehnya dengan bantuan macam macam literatur yang erat hubungan nya dengan masalah yang diteliti oleh penulis.

Penelitian kepustakan dilakukan untuk memperoleh data sekunder.Data sekunder adalah data yang diperoleh dengan data mengumpulkan data mempelajari teori literature serta faktur yang berhubungan dengan penulisan skripsi ini sebagai landasan pembahsan yang ada sehingga dapat diambil kesimpulan terhadap masalah yang diteliti. Penelitian ini dilakukan dengan mempelajari dan menelaah pendapat yang bersifat teoritis dari literatur, undang - undang dan hasil penelitian yang dilakukan oleh para ahli untuk dijadikan landasan teoritis dalam membahas kenyataan yang ditemui dalam penelitian lapangan.

\section{Teknik Analisis Data}

Menurut Sugiyono (2013: 224), Teknik analisis data adalah sebagai berikut,'Teknik analisis Data merupakan langkah yang paling strategis dalam penelitian, karena tujuan utama dari penelitan adalah mendapatkan data".

Dalam melakukan uji keabsahan, terdapat 4 (empat) kriteria untuk melakukan apakah data yang diperoleh peneliti dari lapangan sudah mencapai tingkat keabsahan yaitu : 


\section{Kredibilitas}

Kredibel berarti dapat dipercaya dari prespektif partisipan dalam penelitian itu. Ada beberapa cara untuk meningkatkan kredibilitas yaitu: perpanjangan pengamatan, ketekunan penelitian, diskusi sejawat, dan lain sebagainya.

\section{Transferabilitas}

Transferabilitas merujuk pada tingkat kemampuan hasil penelitian kualitatif dapat digeneralisasikan atau ditransfer kepada konteks atau setting yang lain.Transferabilitas juga bisa diartikan sebagai generalisasi.

\section{HASIL PENELITIAN DAN PEMBAHASAN}

\section{Hasil Penelitian}

Hasil penelitian yang dilakukan yaitu melalui wawancara kepada pihak yang terkait dalam penelitian ini seperti pihak LAZISMU, Akademisi, dan Wajib Pajak dan analisis terhadap data yang diperoleh untuk mengetahui apakah implementasi dan pelaksanakan kebijakan pada kantor LAZISMU di Jakarta Pusat tahun 2018.

\section{Hasil Wawancara}

Dalam Wawancara ini seperti yang telah dijelaskan diatas bahwa peneliti melakukan wawancara kepada beberapa pihak di bawah ini :

Tabel I. Daftar Informan

\begin{tabular}{|c|l|l|}
\hline $\begin{array}{c}\text { No } \\
\text { Informan }\end{array}$ & \multicolumn{1}{|c|}{ Nama Informan } & \multicolumn{1}{|c|}{ Kelompok Informan } \\
\hline 01 & Bapak Nazhori Author & $\begin{array}{l}\text { Selaku Public Relation Manager pada } \\
\text { Kantor LAZISMU di Jakarta Pusat }\end{array}$ \\
\hline 02 & Bapak Edi Suryanto & $\begin{array}{l}\text { Selaku Direktur Kelembagan dan } \\
\text { Kemitraan Corporate Secretary) pada } \\
\text { Kantor LAZSIMU di Jakarta Pusat }\end{array}$ \\
\hline 03 & Bapak Drs. Jiwa Pribadi MM & Selaku Dosen Akademisi Pajak IISMI \\
\hline 04 & Bapak Alief Ramdan S.Sos, M.Si & Selaku Dosen Akademisi Pajak IISMI \\
\hline 05 & Bapak Rizky Febriandi & Selaku Muzakki dan Wajib Pajak \\
\hline 06 & Bapak Rizalianmi Tambunan & Selaku Muzakki dan Wajib Pajak \\
\hline
\end{tabular}

\section{Pembahasan}

Implementasi kebijakan zakat sebagai pengurang penghasilan kena pajak wajib pajak orang pribadi pada kantor LAZISMU Pusat di Jakarta Pusat tahun 2018

Dasar yang ditetapkan pemerintah dalam mebuat kebijakan pastinya bermacam macam. Dalam hal ini itupun juga terjadi pada kebijakan zakat sebagai pengurang penghasilan kena pajak ini.Salah satu yang mendasari lahirnya kebijakan ini adalah karena Indonesia merupakan negara yang mayoritas masyarakatnya muslim. Pemerintah pun melihat ini merupakan potensi yang sangat besar dalam meningkatkan pendapatan dari segi zakat. Tujuan nya jelas yaitu untuk mensejahtrrakan masyarakat.

Sejak berlakunya kebijakan ini di tahun 2001 tentunya pasti akan menimbulkan setiap hal yang akan dihadapi pemerintah. Untuk mencapai keberhasilan dari kebijakan ini, yaitu kebijakan zakat sebagai pengurang penghasilan kena pajak terdapat 6 variabel yang mempengaruhi kebijakan ini yaitu : Standard dan tujuan/sasaran, sumber daya, Karakteristik Badan/Instansi Pelaksana, Komunikasi , Kecenderungan/sikap pelaksana (Dsiposisi Implementor), Kondisi Sosial,Ekonomi dan politik. 
Entitas Penghambat yang Dihadapi Dalam Implementasi Kebijakan Zakat Sebagai Pengurang Penghasilan Kena Pajak Wajib Pajak Orang Pribadi Pada Kantor LAZISMU di Jakarta Pusat Tahun 2018

Dalam pelaksanan kebijakan ini tentunya terdapat kendala yang dihadapi, karena kebijakan itu dibuat pasti selalu ada hal-hal yang menghambat dalam setiap proses nya. Baik itu proses pengenalan sampai dengan proses implementasinya.

Dalam kebijakan Implementasi kebijakan zakat sebagai pengurang penghasillan kena pajak di kantor LAZISMU pusat peneliti dapat menarik kesimpulan tentang hambatan atau kendala yang dihadapi berdasarkan hasil wawancara yang telah dilaksanakan.Hambatan-hambatan tersebut diantaranya sebagai berikut :

1. Sosialisasi yang belum tuntas

Sosialisasi menjadi satu hal yang paling sering dilakukan apabila ada suatu hal baru yang akan dilaksanakan.Kebijakan ini memang mungkin bukan kebijakan yang baru namun dengan adanya beberapa hal yang harus diketahui menjadi inti dari masalahnya.Seseorang yang belum mengetahui kebijakan ini pasti akan bertanya Tanya tentang tata cara atau juknis pelaksanaan nya. Dan orang yang mungkin sudah melakukan program ini dalam artian memvayar zakat tapi tidak mengetahu kebijakan ini pasti hal tesebut akan mengganggu terlaksananya kebijakan ini secara maksimal.

\section{Paradigma Masyarakat}

Masyarakat memiliki presepsi atau pola piker yang berbeda beda dalam hal ini tentunya berkaitan dengan pelaksanaan kebijkan ini maksudnya seorang yang meskipun sudah diberikan penjelasan dan sosialisasi kalaupun dia cuek atau sudah memiliki paradigma sendiri pasti akan susah dalam melaksanakan kebijakan ini.

Entitas Pendorong yang Dilakukan Dalam Implementasi Kebijakan Zakat Sebagai Pengurang Penghasilan Kena Pajak Wajib Pajak Orang Pribadi Pada Kantor LAZISMU di Jakarta Pusat Tahun 2018

Jika suatu kebijakan terbentur dengan kendala atau hambatan pastinya ada Upaya yang dapat dilakukan untuk mengatasi nya atau meminimalisir hambatan yang dihadapi. Dalam hal upaya yang dilakukan dalam implementasi kebijakan zakat sebagai pengurang penghasilan kena pajak pada kantor LAZISMU di Jakarta Pusat, peneliti menarik kesimpulan bahwa kendala itu bisa dihadapi dengan perlakuan yang tepat. Upaya ini peneliti rumuskan berlandaskan dengan hasil wawancara yang sudah dilakukan sebelumnya. Upaya yang dilakukan dengan tepat, terstruktur dan efisien diyakini mampu mengatasi kendala yang dihadapi. Upaya tersebut diantaranya:

\section{Melakukan Sosialisasi yang mendalam}

Sosialisasi yang dilakukan secara tepat dan langsung mengenai target dari sasaran kebijakan pasti akan menimbulkan ketidaktahuan masyarakat akan kebijakan tersebut sedikit demi sedikit sirna. Dengan adanya sosialisasi yang mendalam berarti sosialisasi ini dilakukan dengan terstruktur, maksudnya adalah sosialisasi diadakan dalam waktu tertentu. Kemudian mendalam artinya dilakukan oleh orang orang yang dirasa mampu memberikan kepercayaan public yang kuat. Seperti sosialisasi langsung dari pemerintah dalam hal imi DJP, Kemnetrian, ataupun amggota yang berwenang.

2. Memberikan Pengawasan dan Evaluasi

Pengawasan dan evaluasi kebijakan menjadi suatu hal yang harus dilakukan setelah adanya sosialisasi. Sosialisasi menjadi tidak efektif apabila tidak ada lagi tindak lanjut ataupun evaluasi. Dalam kebijakan ini tentunya setiap adanya suatu kesalah harus langsung dicari perbaikan nya. Apabila ada sesuatu yang lamban harus langsung dicari penyelesaian nya. Hal inilah yang membuat setiap kendala dan masalah akan bisa dihadapi.

\section{KESIMPULAN}

Berdasarkan hasil pembahasan pada bab sebelumnya meneganai Implementasi Kebijakan Zakat Sebagai Pengurang Penghasilan Kena Pajak Wajib Pajak Orang Pribadi Pada Kantor LAZISMU di Jakarta Pusat, maka dapat dijelaskan pada kesimpulan dan saran sebagai berikut : 
1. Implementasi kebijakan zakat sebagai pengurang penghasilan kena pajak wajib pajak orang pribadi di tinjau dari variabel-variabel penentu keberhasilan implementasi kebijakan yang dirumuskan oleh Van Meter dan Van Horn dapati dikatakan bahwa berhasilnya suatu kebijakan itu terdapat 6 variabel, yaitu Standard dan sasaran kebijakan, Sumber sumber kebijakan, Karakteristik agen pelaksana, Hubungan antar organisasi, disposisi atau kecenderungan pelaksana, dan Kondisi Sosial, Ekonomi, dan Politik. Dari setiap variable tersebut tedapat Indikator-Indakotor yang harus di penuhi. Keberhasilan yang didapatkan dari Implementasi Kebijakan tersebut pasti akan menimbulkan suatu dampak yang baik. Keberhasilan itu mampu menjadikan pihak LAZISMU lebih meluaskan lagi setiap setiap program. Baik program baru maupun program lanjutan. Keberhasilan tersebut juga akan berpengaruh terhadap terbentuknya kondisi muzakki yang mengerti dan semakin memahami visi dan misi dari lembaga LAZISMU. Dan pada akhirnya hal tersebut akan berujung pada tercapai nya setiap program dan meningkatnya pendapatan dari hasil penghimpunan ZIS. Meskipun grafik penerimaan nya cenderung meningkat hal tersebut masih bisa dimaksimalkan lagi untuk meraih potensi yang sebesar besarnya. Dengan demikian LAZISMU bisa menjadi Lembaga Zakat yang mampu memberikan pengaruh Ekonomi dan sosial masyarakat Indonesia ke arah yang lebih baik.

2. Dalam pelaksanaan Implementasi Kebijakan Zakat Sebagai Pengurang Penghasilan Kena Pajak pada Kantor LAZISMU masih menghadapi beberapa hambatan atau kendala diantaranya :

a. Masih banyaknya ketidaktahuan masyarakat terhadap kebijakan zakat sebagai pengurang penghasilan kena pajak

b. Adanya keterbatsan sumber daya baik dari jumlah maupun kemampuan

c. Adanya pandangan masyarakat yang sulit untuk berikan sosialisasi maupun edukasi program

d. Regulasi yang kurang signifikan

e. Krisisnya kepercayaan masyarakat terhadap lembaga atau pemerintah

Kendala-kendala tersebut dikhawatirkan akan mempengaruhi berbagai hal didalam Kantor LAZISMU jika tidak segera diselesaiakan dan dicari solusinya. Pengaruh tersebut bisa juga menjadi salah satu sebab gagalnya pencapain target atau penghimpunan, dan juga tidak terlaksananya program secara maksimal.

\section{Saran}

Berdasarkan Kesimpulan diatas maka penulis ingin menyampaikan beberapa saran yang kiranya dapat digunakan sebagai solusi penyelesaian masalah yang sebelumnya sudah penulis sampaiakn pada Upaya yang dapat dilakukan pada bab sebelumnya.Berikut saran yang ingin penulis sampaikan :

a. Melakukan sosialisasi yang mendalam agar setiap lapisan elemen dalam masyarkat mengetahui tentang adanya kebijakan ini.Jika bisa libatkan pemerintah atau pihak berwenang yang bisa menciptakan kepercayaan publik dalam setiap penjelasan nya.

b. Mengadakan pengawasan dan evaluasi agar setiap kebijakan berjalan dengan baik.Apabila ditemukan masalah langsung diperbaiki agar masalah tidak terus terakumulasi.

c. Menciptakan Kepercayaan Publik dengan memeperkuat sifat sifat Amanah, Profesional, dan Transparan .Dengan demikian hal terbut mampu membuat meningkatkan kepercayaan masyarakat dan dengan sendirinya masyarakat akan memberikan dukungan teerhadap setiap program yang akan dibuat dan yang sedang dijalankan.

\section{DAFTAR PUSTAKA}

\section{Buku}

Ali, F. 2011. Teori dan Konsep Administrasi. Jakarta: PT. Raja Grafindo Persada.

Cresswell, John W. 2014. Penelitian Kualitatif\&Desain Riset. Yogyakarta: Pustaka Pelajar.

Diana, Sari. 2013. Konsep Dasar Perpajakan. Bandung: PT. Refika Adimata.

Djuanda, Gustian,dkk. 2006. Pelaporan Zakat Pengurang Pajak Penghasilan. Jakarta: Raja Grafindo.

Gunadi, Djoned M. 2005. Administrasi Pajak. Jakarta: Departemen Keuangan.

Inayah, Gazi. 2003. Teori Komprehensif Tentang Zakat dan Pajak. Yogyakarta: PT. Tiara Wacana Yogya.

Jawad, Muhammad. 2007. Fikih Lima Mazhab. Jakarta: Lentera.

Juliansyah,Noor. 2011. Metodologi penelitian:Skripsi, Thesis, Disertasi, dan Karya Ilmiah. Jakarta: Kencana. 
Keban, Yeremias T. 2008. Dimensi Strategis Administrasi Publik: Konsep, Teori, dan Isu Edisi Kedua. Yogyakarta: Gaya Media.

Mardiasmo. 2016. Perpajakan Edisi Terbaru. Yogyakarta: UNY Press.

Moeleong, Lexy J.2016. Metode Penelitian Kualitatif Edisi Revisi. Bandung: PT. Remaja Rosdakarya.

Mursyidi. 2006. Akuntansi Zakat Kontemporer. Bandung: Remaja Resdakarya.

Neuman, W. Lawrence. 2013. Metodologi Penelitian Sosial : Pendekatan Kualitatif dan Kuantitatif Edisi 7. Penerjemah: Edina T. Sofia. Jakarta: PT Indeks.

Nugroho, Riant. 2012. Public Policy. Jakarta: Gramedia.

Pasolong, Harbani. 2010. Teori Administrasi Publik. Bandung: Alfabeta.

Prastowo, Andi. 2010. Menguasai Teknik-teknik koleksi data penelitian kualitatif. Yogyakarta : DIVA Press.

Rahman, Abdul. 2010. Panduan Pelaksanaan Administrasi Pajak: Untuk Karyawan, Pelaku Bisnis dan Perusahaan. Bandung: Nuansa.

Resmi, Siti. 2017. Perpajakan: Teori dan Kasus. Jakarta: Salemba Empat.

Sabiq, Sayyid. 2008. Fiqih Sunnah Juz II. Bandung: PT. Al-Ma’arif.

Satori, Djaman dan Komariah, AAN. 2012. Metode Penelitian Kualitatif. Bandung: Alfabeta.

Siagian P, Sondang. 2008. Administrasi Pembangunan, Konsep, Dimensi, dan Strateginya. Jakarta: Bumi Aksara.

Subarsono, AG. 2006. Analisis Kebijakan Publik: Teori, Proses, dan Aplikasi. Yogyakarta: Pustaka Pelajar. 2012. Analisis Kebijakan Publik: Teori, Proses, dan Aplikasi. Yogyakarta: Pustaka Pelajar.

Sugiyono. 2011. Metode Penelitian Kuantitatif, Kualitatif, dan R\&D. Bandung: Alfabeta. .2011. Metode Penelitian Kuantitatif, Kualitatif, dan R\&D. Bandung: Alfabeta. 